\title{
Interaction of socio-economic factors and real estate market in the context of sustainable urban development
}

\author{
Ineta Geipele ${ }^{\mathrm{a}}$, Linda Kauškale ${ }^{\mathrm{b}}$, Natalija Lepkova ${ }^{\mathrm{c}}$, Roode Liias ${ }^{\mathrm{d}}$ \\ ${ }^{a, b}$ Department of Civil Construction and Real Estate Management, Riga Technical University, 6 Kalnciema Str., Riga, LV-1048, Latvia \\ ${ }^{c}$ Department of Construction Economics and Real Estate Management, Vilnius Gediminas Technical University, \\ Sauletekio av. 11,10223 Vilnius, Lithuania \\ ${ }^{d}$ Faculty of Civil Engineering, Tallinn University of Technology, Ehitajate tee 5, 19086 Tallinn, Estonia
}

\begin{abstract}
This article in general reflects the significance of socio-economic factors and the real estate market in sustainable urban development. The relevance of the research is being determined by the high ratio of the real estate market and construction industry in Latvian and Baltic economic structure, as well as well as their major impact on the state socio-economic status. The objective of the research is to identify the major problems existing in the sustainable development of real estate industry for improvement of the situation. The particular attention will be paid to the problems of socio-economic aspects and related macroeconomic indicators. On the basis of the results of the research the proposals for advancement of sustainable and competitive development are prepared. The subject of the research is an interaction of socio-economic factors and real estate market over the period from 2009 to 2013. The article reflects the impact of Latvian national economy and real estate market on the sustainable urban development, as well as the main trends in the real estate market and the socio-economic sphere of the country, in the overall context of the development of the Baltic States. The role of the state is reflected in the socio-economic processes regulation, interaction of the economy and real estate market development, factors influencing the house building, the main challenges and directions of Latvian sustainable development strategies, as well as the correlation of some macroeconomic indicators in terms of sustainable development. On the basis of the conducted study, the main trends in the sustainable development of the real estate market and in the socio-economic sphere have been defined, as well as recommendations on improvement of the situation in the longer term and preventive measures have been developed. The historical, logical, analytical and comparative methods have been used in the article.
\end{abstract}

Keywords: real estate market; national economy; development; regulation; socio-economic factors; Baltic states.

\section{Introduction}

Supporting sustainable development is important in order to have several apparent stable positive trends in the development of the state, cities and economics. However, it is not easy simultaneously to achieve the ideal situation in the country, which would be beneficial to everyone, and to maximize the effective indicators at all stages, as even such indicator as inflation has both positive and negative effects: on the one hand the rise in the price level reduces the purchasing power, but the rise in consumer prices at the same time shows the country's economic development, which is also significant. In any case, it is necessary to add the motivating factors in the sustainable development planning, to motivate the market participants to act in accordance with the principles of sustainability.

The objective of the research is to identify the major problems existing in the sustainable development of real estate industry for improvement of the situation. The particular attention is being paid to the problems of socio-economic aspects and related macroeconomic indicators. On the basis of the results of the research the proposals for advancement of sustainable and competitive development are prepared. The subject of the research is an interaction of socio-economic factors and real estate market over the period from 2009 to 2013.

Currently, more and more attention is paid to the relevant problems and researches in relation to the promotion of the sustainable development in several areas. If to describe 'sustainability' and 'sustainable development', as an aggregate of characteristics including economic security and growth, environmental quality and integrity, social cohesion and quality of $\underline{\text { life, empowerment and governance [1], the part of the real estate market and construction industry in the promotion of the }}$

Corresponding author: Linda Kauškale. E-mail address: Linda.Kauskale@rtu.lv

http://dx.doi.org/10.3846/enviro.2014.117

(C) 2014 The Authors. Published by VGTU Press. This is an open-access article distributed under the terms of the Creative Commons Attribution License, which permits unrestricted use, distribution, and reproduction in any medium, provided the original author and source are credited. 
sustainable development is understandable, as they have a high ratio in Baltic economic structure, as well as well as they have major impact on the state socio-economic status.

Real estate is inseparable from human economy in its social form, and all plans of social reform better be directed toward an appropriate distribution of economic goods [2]. The attention is paid at the present moment as well, as the number of people at risk of poverty or social exclusion is a headline indicator used to measure progress in meeting the goals of the Europe 2020 strategy, namely to have at least 20 million fewer people at risk of poverty or social exclusion by 2020 [3]. In 2011 , there were 119.6 million people in the EU-27, equivalent to $24.2 \%$ of the entire population, who lived in households facing poverty or social exclusion [4]. Classical economists from Adam Smith [4] through John Stuart Mill [66] were concerned with the growth of the wealth of nations and its distribution among functionally defined economic classes. Neoclassical economists dealt with the allocation of resources in a static society. Keynesian economics was devoted to macroeconomics and the problems of employment. Modern economics is heavily mathematical, with the general equilibrium model as a focus [7]. According to NAP2020 strategic indicators, the economic breakout consists of the national economy growth, growth in the relevant areas and human resilience [8].

Several studies have already been conducted, and it is understandable that after the depression in the XXI century the new fundamental discoveries are expected, like it was in the twentieth century after the Great Depression. According to Ivars Brivers [9] this could include the growth of the state involvement, restriction of the speculative economics, satisfaction of needs of the domestic demand, by making the economics less dependent on external oscillations and gradual abandonment of monetary indicators for measuring economic objectives, thus making the decisive productivity rather than profitability.

\section{Socio-economic factors and real estate market: the main interrelation aspects and Baltic states experience}

The development of the state national economy and the overall real estate market has in general a significant impact on urban development [10]. The macroeconomic effects of fiscal policy was studied by Antonio Afonso and Ricardo M. Sousa [11], who described also the positive impact of the government spending on the several indicators, including the real estate prices. The interrelationship between housing supply and monetary policy within the context of global economic turbulence by a VEC-D model was studied by Junxiao Liu and Kerry London [12].

Sustainable housing is a key factor that affects the socio-economic status. Index calculations for the apartments in new projects in the Baltic capital in the city districts show that the highest index value is $32.2 \mathrm{~m}^{2}$ in Tallinn, $26.9 \mathrm{~m}^{2}$ in Vilnius, while only $22.6 \mathrm{~m}^{2}$ in Riga (accessibility index values are used for calculating the credit conditions for the down payment in the amount of $20 \%$, for 25 years, the average loan interest rate) [13].

Sustainable housing affordability by using multiple criteria decision making method was researched in ,An assessment of sustainable housing affordability using a multiplecriteria decision making method" [13] and methodology could be adopted by a number of interested parties. Economic conditions of residents affects housing maintenance and the quality of improvements, that's why most European countries offer loan systems for renovation [15].

In order to successfully implement sustainable real estate market strategy, the real estate market should be controlled to avoid the real estate market overheat. A warning sign occurs when housing supply exceeds a certain investment scale, and to determine the supply capacity of the real estate market need to analyse: investment amount of commodity housing projects, area of developed land and area of new commodity housing projects [16]. For example Brauers Willem, Kildienè Simona et al. [17] for countries that entered the crisis with a housing bubble and a large net foreign liability position make a recommendation to shift activity from construction to export-oriented activities and to diminish their dependency on external financing.

In World Economic Outlook [18] it is recommended, that policies should aim to nurture the recovery and reduce vulnerability from still elevated fiscal and current account deficits in some countries. Also the regulation of excessive demand through mortgage-lending policies can assist in controlling this growth of house prices [19]. Downward trend in the housing credit market is halting in Estonia and Lithuania but continuing in Latvia, despite the fact that the volumes of new loans have increased the most in Latvia (in the first half of 2013 by 25 per cent compared to that of a year ago), but it does not outweigh the repayments and write-offs of the current loans [20].

Interaction between real estate and macroeconomics figure out in interaction between Real estate Sector and GNP in the macroeconomics with the following indicators [21]:

- Incomes: rents and direct employment;

- Equity release;

- Investment;

- Space for living and producing;

- Collateral for loans and business;

- Housing derived demand-increases in a boom; decreases in recession;

- Land for food production.

The factors influencing the real estate investment strategies shall be distributed by the following categories: economic factors, political factors, social factors, environmental factors, science and technology factors and subjective factors. The most comprehensive is the group of economic factors, and it consists of the macroeconomic, microeconomic, business 
factors, economic development cycles, foreign economic activity, economic globalization and national economic policy factors [22].

Considering the fact that development is being significantly influenced by the financial options (along with effective decision-making), the opportunities to attract foreign investment should be assessed. External investment attraction opportunities depend on the globalization level of the country. It has been shown [23] that, contrary to the beliefs of its critics, globalization indeed promotes growth, countries that globalized more, experienced higher growth rates and crossborder information flows promote growth (according to research in period 1996-2000 there were 82 countries with high globalization and 40 with low globalization level - total 123 countries analysed; it was mentioned, that the high ratio of globalization is nearly impossible to achieve in the short term). Table 1 contains information only about the Baltic countries, which have been selected for the analysis, and their globalization indicators in 2000, which can determine that the highest overall level of globalization among the Baltic countries is in Estonia, the only stage, at which the level of globalization is lower in Estonia than in the other Baltic countries, is the political integration.

Table 1. Ratings of globalization [23]

\begin{tabular}{lllll}
\hline Country/Indicator & $\begin{array}{l}\text { Economic integration } \\
2000\end{array}$ & $\begin{array}{l}\text { Social integration } \\
2000\end{array}$ & $\begin{array}{l}\text { Political integration } \\
2000\end{array}$ & $\begin{array}{l}\text { Summary rating } \\
2000\end{array}$ \\
\hline Estonia & 5.81 & 2.64 & 1.44 & 3.43 \\
\hline Latvia & 4.94 & 2.25 & 1.54 & 2.99 \\
\hline Lithuania & 4.66 & 1.79 & 1.74 & 2.78 \\
\hline
\end{tabular}

* Notes: all indexes range from 0 (not globalized) to 10 (globalized). The countries are ranked according to their overall index score in 2000. Rating less than 2.45 - countries with low globalization, more than 2.45 - countries with high globalization.

Real GDP per capita is one of indicators, that reflects the economic development, and the growing trend of the indicator can be observed in the Baltic States at the present moment - over the period from 2009Q1 to 2013Q2 Real Gross Domestic Product per capita most of all increased in Lithuania (about 23.53\%), in Latvia for 20\%, and the least in Estonia - $14.29 \%$ [24]. Despite the fact that the Latvia had the highest rates of GDP growth on a quarterly basis in the Baltic countries in 2013, the highest GDP per capita in the Baltic States is still in Estonia.

According to the research by Eddie C. M. Hui and Ka Kwan Kevin Chan [25], during a financial crisis, correlation of a type of asset market between two countries usually increases, i.e. they either move up together or, more commonly, move down together, and even correlation between different types of asset markets may increase, too. This regularity is presented by the example of the Baltic States in Figure 1, where cyclical nature of unbalanced development of the real estate price dynamics can be also observed. In the period from 2006 by 2012 in the Baltic countries there has been observed the function non-compliance with a linear trend, as well as the sharpest decline in indicators in comparison with other countries (Fig. 1).

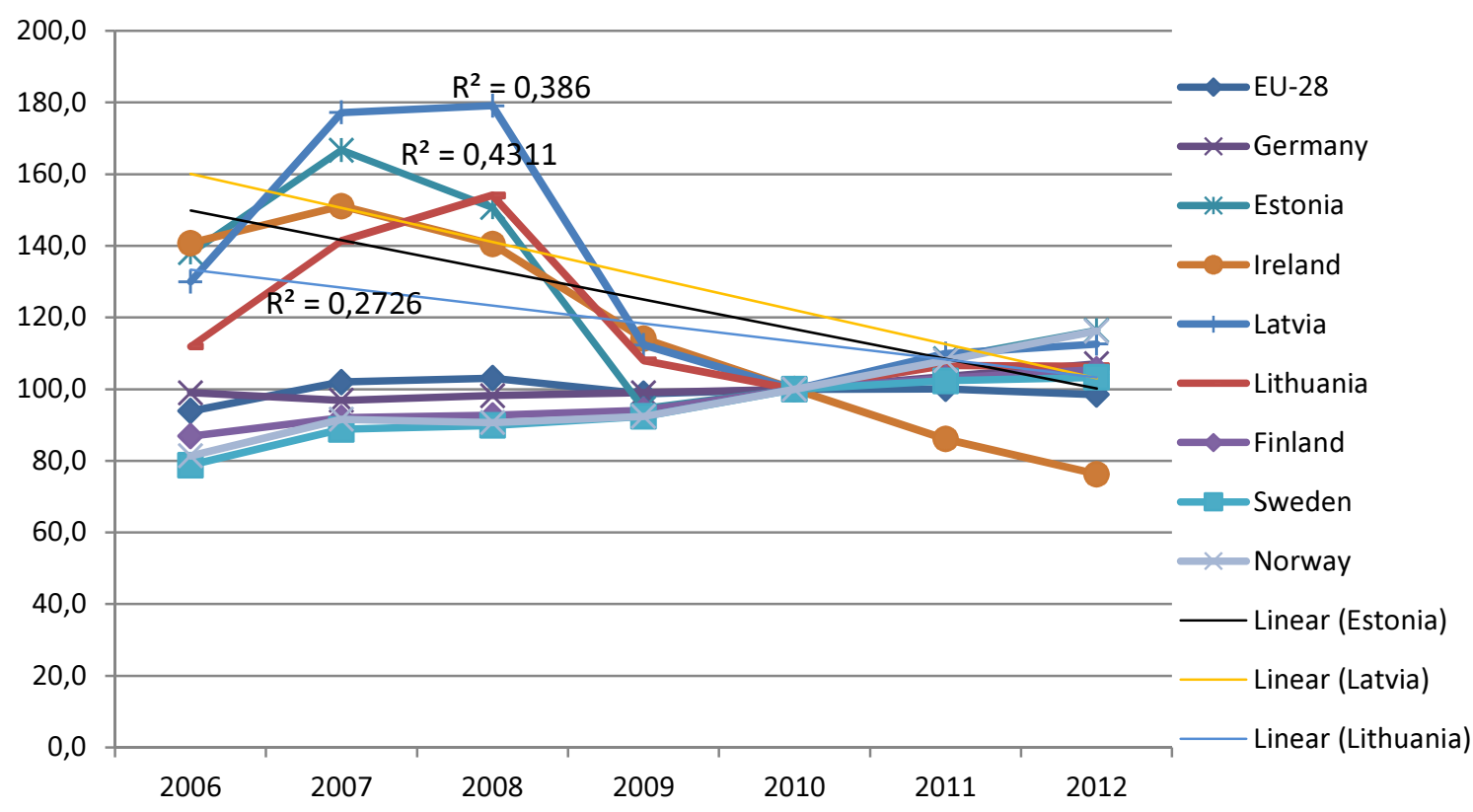

Fig. 1. House price index, $2010=100$ Data source: Eurostat, calculations of authors

At the same time, Figure 1 shows that in Sweden and Finland the decline in the real estate market was not observed, one of the reasons is the cooperative house system, which is being widely used in these countries. 
The CORREL and PEARSON worksheet functions both calculate the correlation coefficient between two sets of values, when measurements on each variable are observed for each of $\mathrm{N}$ subjects, and the value of any correlation coefficient must be between -1 and +1 inclusive [26]. The Excel CORREL function is shown as Eqn (1).

$$
\operatorname{cor}(x, y)=\frac{\sum_{i=1}^{n}\left(x_{i}-\bar{x}\right)\left(y_{i}-\bar{y}\right)}{\sqrt{\sum_{i=0}^{n}\left(x_{i}-\bar{x}\right)^{2} \sum_{i=1}^{n}\left(y_{i}-\bar{y}\right)^{2}}}
$$

GDP correlation index of the Baltic countries in the short and longer term is presented in Table 2.

Table 2. GDP correlation index of the Baltic countries

\begin{tabular}{lll}
\hline & GDP at market prices & GDP at market prices \\
& $2006-2012$ & $2010 \mathrm{Q} 1-2013 \mathrm{Q} 3$ \\
\hline Latvia-Estonia & 0,867312 & 0,9906532 \\
\hline Lithuania-Estonia & 0,871356 & 0,998313 \\
\hline Lithuania-Latvia & 0,826931 & 0,990725 \\
\hline
\end{tabular}

In the short term the correlation index of the Baltic countries is very high, it is evident that the GDP dynamics development goes in one direction, in the longer term correlation index is lower, but still at the high level. In the longer term, from 2006 up to 2012 the closest connection is between Estonia and Lithuania, then between Latvia and Estonia, and only then follows the connection between Latvia and Lithuania.

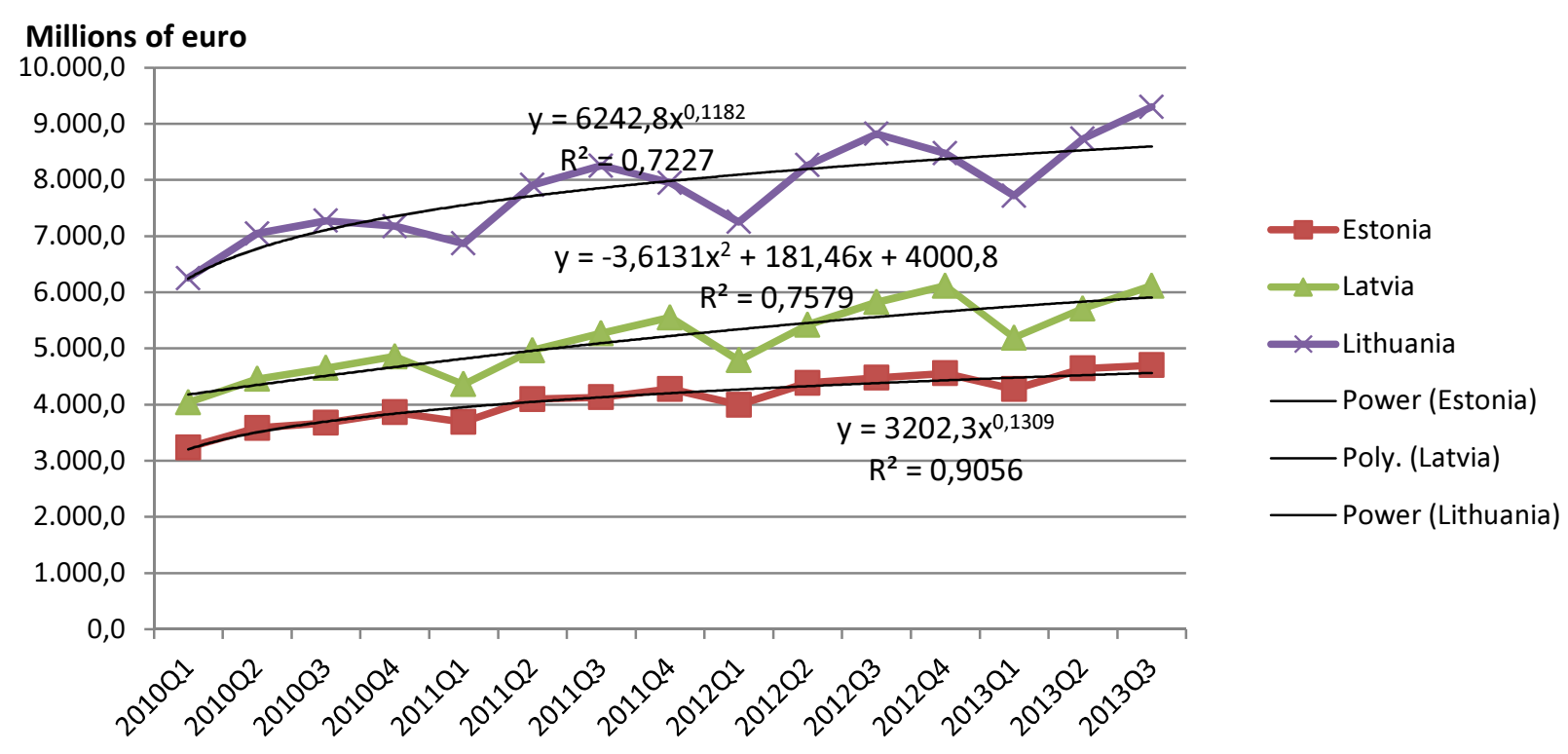

Fig. 2. Gross domestic product at market prices, Data adjusted by working days, Millions of euro Data source: Eurostat, calculations of authors

While analyzing the GDP development of the Baltic States, since the beginning of the rising phase, it can be concluded that at the moment Latvian GDP development trends look a little less corresponding to the solid growth in the Baltic countries, as they are mostly in conformity with the polynomial function with a negative index, while Estonia and Lithuania are approaching the degree functions with the degree below "1". The further analysis of GDP development dynamics will enable further observation and clarification of the trend in the longer term.

According to GDP annual growth rate forecast [27] data, in the years 2014 and 2015, the fastest GDP growth rates in the Baltic countries are predicted to be in Latvia - by $4.1 \%$ and $4.2 \%$ respectively. The growth in Lithuania is predicted to be $3.6 \%$ in 2014 and $3.9 \%$ growth in 2015 , while in Estonia $3.0 \%$ and $3.9 \%$.

\section{The main Sustainable Urban development aspects}

Investments in real estate and its trends may affect future supply of real estate objects in the city and its development trends. The indicator, which is more interesting for the investors at the given time while making decisions about investing in real estate, is usually the real estate yield upon risk assessment, which characterizes the amount in cash (in percentage) that returns to the owners of a real estate. In 2013Q3 Riga and Vilnius both have the same prime office yield, prime retails yield and prime rental yield indicators $-8.00 \%, 7.75 \%$ un $9.00 \%$ respectively; the rates in Tallinn are a few percentage points 
lower - prime office yield and prime rental yield both are 7.5\%, prime industrial yield is almost like in Riga and Vilnius $8.9 \%$ [28]. Investors should carefully assess the investment environment and develop of real estate investment strategy to make the developed project satisfy the needs of all parties involved (interest groups), and comply with the principles of sustainability by satisfying needs of the parties involved (inhabitants, developers, government organizations, etc.).

One of the most important indicators that affect the housing affordability is household income. If to consider only the average wage and the average price of new projects, the employee in Tallinn for average year income could buy $7.1 \mathrm{~m}^{2}$ large area in the new project (which is about 30\% more than in Vilnius and Riga). Under the same conditions, the Vilnius citizens can afford $5.5 \mathrm{~m}^{2}$ large area, but the average employee in Riga could buy only $5.3 \mathrm{~m} \mathrm{[13].}$

Now the urban development of major Baltic cities generally assumes the characteristics of „sprawl without growth” [29] - the extensive urban sprawling during rapid demographic and also economic (at recent period of recession) decline. The demographic trend is one of the most important factors in urban development planning. According to Eurostat [24] data, the total EU-28 population in the period from 2013 to 2004 has increased by $2.86 \%$, declined in Latvia by $11.10 \%$, in Lithuania by $12.56 \%$. In declined the least in Estonia compared to Latvia and Lithuania - by $2.48 \%$. Now the development of Baltic cities is mainly influenced by private needs of real estate owners and commercial interests of real estate developers [30]. A problem of coordinating private investments in residential neighbourhoods, industrial parks, and commercial centres with public investments in roads, sever lines, and parks was researched by Gerrit-Jan Knaap [30], where he critiques the „,pricing” (using prices, taxes and fees) approach in solving urban sprawl problems, because the urban sprawl problems involves much more than urban expansion or falling urban densities, social welfare is a function of many attributes of urban form and much of the character of urban growth is shaped by public investments in road networks, sewer systems, and public parks, because these public investments are largely unaffected by the price system.

According a State Unified Computerised Land Register statistic data [31], in terms of the amount of business in the Latvian capital Riga and other Latvian territory, over the period from 2004 to 2013, the relative share of business dealings in ranged from $24.68 \%$ (in 2010) to $31.43 \%$ (in 2004). The least amount of the business dealings was reported in 2010 . At the rising phase in 2013 compared to 2010, the amount of business dealings in Riga increased by $58.05 \%$, but the number of dealings is still less than in 2004. 29.33\% of the total amount of business dealings in Latvia in 2013 was implemented in Riga, but $12.64 \%$ - in the Riga region. So the total amount of business dealings in Riga and Riga region in 2013 composed $41.96 \%$ that determine the uneven trends of real estate market development in Latvia.

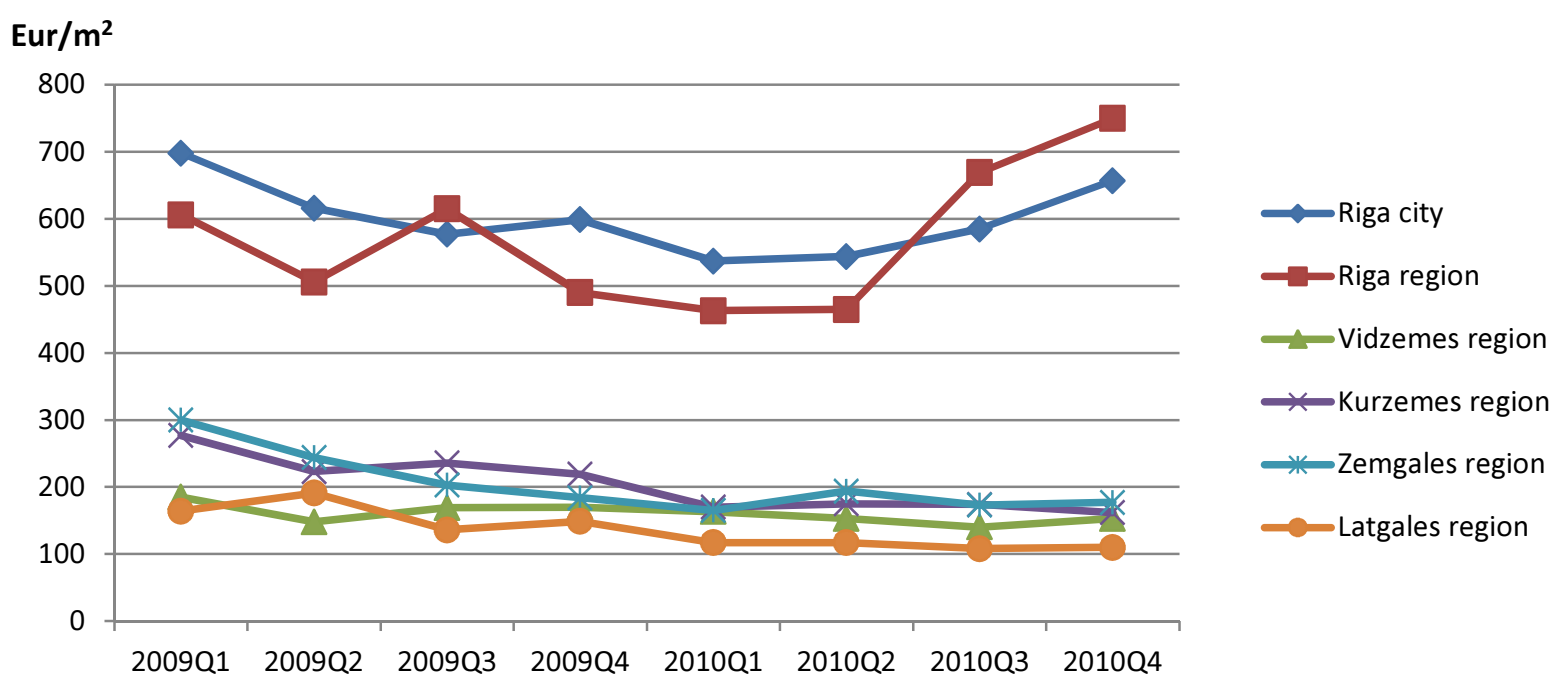

Fig. 3. Total value of $1 \mathrm{~m}^{2}$ of all sold apartments in Latvia, euro Data source: Central Statistical Bureau of Latvia

According to Central Statistical Bureau of Latvia data [32], uneven real estate market development in Latvia shows also the difference at the price level between Riga and other Latvian regions (Fig. 3). Even when the economic situation changed for better, the development of several regions of the country was not progressing so rapidly as in Riga. One of the solutions of the complex problems of socio-economic development of the country in the nowadays situation could be the markets of primary housing, roads and railways, production and non-production facilities [33].

Many cities have recognized the need to increase engagement with stakeholders of all kinds, including the very important group of private sector building owners; in general the market of real estate owners is willing to act when presented with forward-looking regulations and meaningful incentives, so it can give a possibility to create more valuable, more resilient building stock that benefits all [34]. For example the use of public facilities in the construction is positively affecting the business sector, not only due to the increase of the working positions and other economic aspects, but also the final construction product is important to the public.

Economic development policies can be characterised in many ways - by their overall aims, by the type of targeted economic activity, by the preferred spatial distribution, and by associated support measures (including a skilled workforce and employment land), and economic development aims tend to vary by sub-region [35]. It is important to plan sustainable 
development in advance. Now such tendencies are widely observed while planning - the first was a limiting of the ambition of planning by government, given the widespread political ascendancy of business interests in Europe, the second tendency was the possible move towards some common European understanding of ,spatial planning”, spatial planning is therefore taken to include regional policy as well as regional and local land use planning, reaching social, economic and environmental objectives [35].

Figure 4 shows the example of Latvia, where the GDP, the average wages and amount of real estate dealings are presented for the analysis of the indicator development in the period from 2004Q1 to 2013Q3.
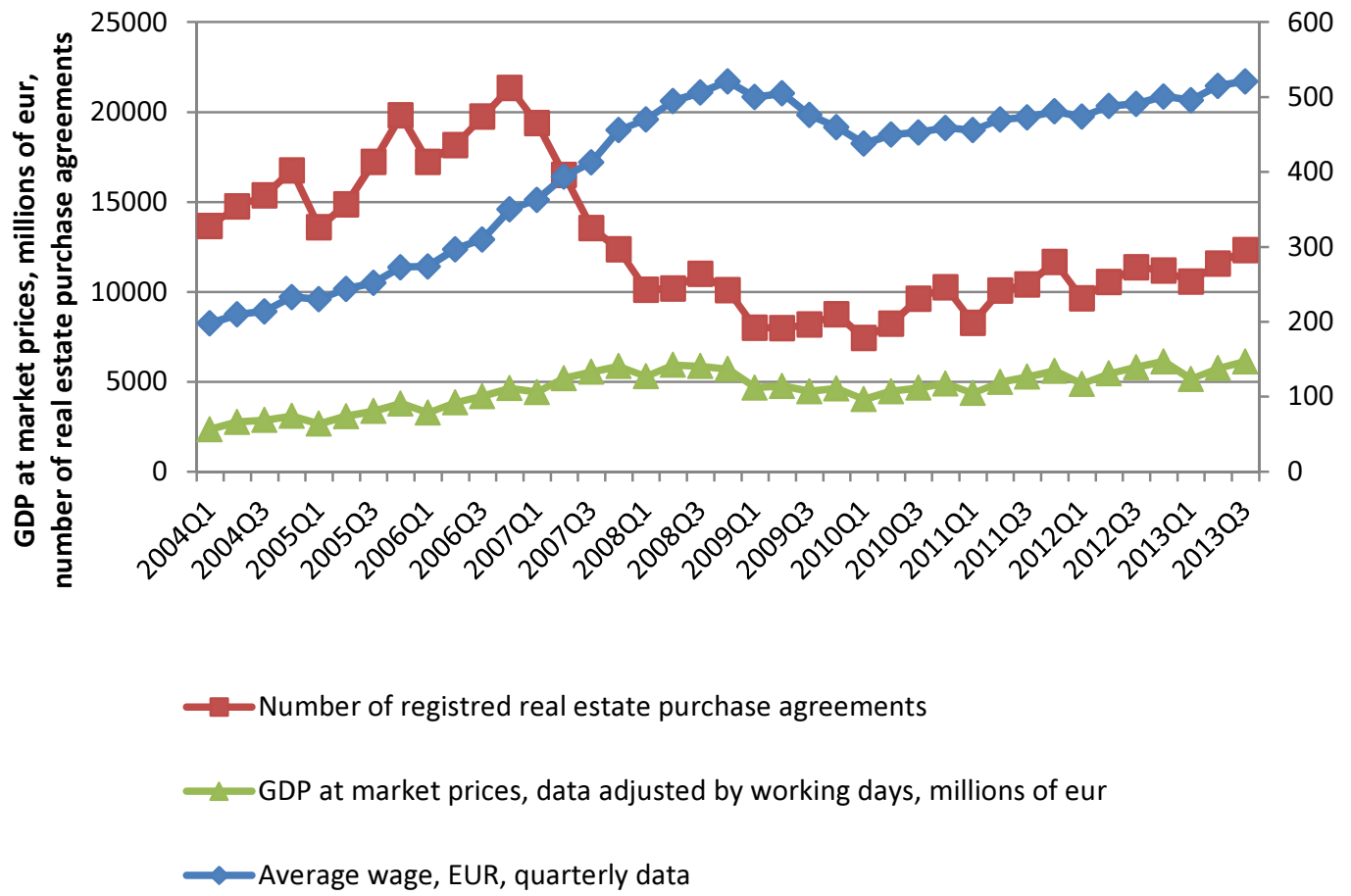

Fig. 4. GDP at market prices, average wage and real estate purchase agreements Data source:Central Statistical Bureau of Latvia, A State Unified Computerised Land Register, Eurostat

The amount of registered real estate deals in 2013 increased by $43.58 \%$ compared to 2009 , when there was observed the lowest amount of deals in Latvia in the period under study, but it is still up to $21.92 \%$ less than in 2004. Figure 4 shows that the largest amount of real estate transactions was observed in 2006. However, the total satisfied demand in the real estate market, as well as the average selling price per square meter of housing in the market according to Latvian Central Statistical Bureau data, peaked exactly in 2007 [36]. This means that real estate prices in Latvia had a greater impact on the total accumulated amount of money in the real estate market than the total number of business dealings. In such situation the classical law of supply and demand can be observed - rise in price causes the decline in the number of deals.

According to the results of the study on interaction aspects of socio-economic factors and real estate market development, by using Eqn (1), the correlation of the Latvian GDP and the average price per 1 square meter over the period from 2004 to 2009 was very strong - 0.9482. In the shorter term, at the economic rising phase over the period from 2010Q1 to 2013Q4, there was very strong correlation between Latvian GDP and turnover in the real estate industry - the correlation coefficient is 0.9138 . The short term period from 2010Q1 to 2013Q3 coincides with the rising phase in Latvia. In the short term, the number of registered business dealings has a slightly larger correlation with GDP than with wages (see Table 3).

Table 3. Correlation of socio-economic factors and real estate market development (authors' calculations, by using Central Statistical Bureau of Latvia, A State Unified Computerised Land Register and Eurostat data)

\begin{tabular}{llll}
\hline COR (x,y) & Average wage, EUR, quarterly data & $\begin{array}{l}\text { Number of registered real } \\
\text { estate purchase agreements }\end{array}$ & $\begin{array}{c}\text { Construction production } \\
\text { volume, millions of eur }\end{array}$ \\
\hline $\begin{array}{l}\text { GDP at market prices, data adjusted } \\
\text { by working days, millions of EUR }\end{array}$ & & & 0,8558 \\
\hline short term 2010Q1-2013Q3 & 0,9138 & 0,9482 & 0,7079 \\
long term 2004Q1-2013Q3 & 0,8991 & $-0,4143$ & \\
\hline $\begin{array}{l}\text { Number of registred real estate } \\
\text { purchase agreements }\end{array}$ & & & 0,8154 \\
\hline short term 2010Q1-2013Q3 & 0,8822 & & \\
\hline
\end{tabular}


The correlation of the amount of registered real estate business dealings and GDP in the longer term in Latvia over the period from 2004Q1 to 2013Q3 is not observed, as the development of development cycles in Latvia was not identical - the highest number of business dealings was in 2006, but GDP peaked in 2008 (see Fig. 4) - the number of deals in the real estate market began to decline faster than during the recession in the economy. In case of Latvia after decreasing the number of registered dealings it took 2 years to see GDP to fall in the last phase (according to Fig. 4). The correlation at the rising phase between these indicators is stronger than in the longer period, and the level of correlation depends on the economic development phase and period under study.

The correlation index between construction industry development and GDP, in comparison with other investigational indicators, is lower, because the construction industry is not so quickly responding to the changes in demand. Secondly, this sector has even more pronounced seasonal character. As most investors begin to be activated with the increase in demand, and since the construction consists of several stages, the situation may change as of the date of the completion of the object.

\section{Conclusions}

The development of the total national economy and real estate market has a significant impact on urban development. The problem is in the cyclical and unbalanced nature. Over the period from 2006 to 2012 there has been observed in the Baltic countries the noncompliance of the real estate price dynamics to the linear trends, as well as the sharpest decline of indicators in comparison with other countries under study. $41.96 \%$ of all dealings in Latvia were executed in Riga and Riga region. Uneven real estate market development in Latvia shows also the difference at the price level between Riga and other Latvian regions. Even when the economic situation changed for better, the development of several regions of the country was not progressing so rapidly as in Riga. At the present moment, the development of Baltic States is mainly influenced by private needs of real estate owners and commercial Interests of real estate developers.

In the shorter term social condition, economic conditions and real estate market development correlation is at the high level. This means that the improvement of the state socio-economic situation has a positive impact on the real estate market. The correlation index of Latvian GDP and average price per 1 square meter over the period from 2004 to 2009 is very high (0.9482), which characterizes this connections as very strong, so the GDP development dynamics will also affect the real estate prices. In the shorter term social condition, economic conditions and real estate market development correlation is at the higher level than in the longer term. The level of correlation depends on the economic development phase and period under study. In the longer term, the cyclical development of Latvian GDP and the real estate market creates difficulties for the real estate market participants in relation to the analysis of the situation in the longer term. At the present moment, the most favourable situation in terms of GDP per capita and housing index in the Baltic countries is in Estonia. In 2000 there was observed In Estonia the highest socio - economic integration globalization level, although in the nearest future the fastest growth rates in several indicators is expected to be in Latvia.

The construction sector and real estate dealings have quite a large share of total national GDP, and they can directly and indirectly affect each other. In the short term, GDP correlation index in the Baltic countries is very high, it is evident that GDP development in the Baltic countries goes in the same direction, in the longer term, the correlation index is slightly lower, but still at the high level. In future researches can be useful to analyse larger number of countries by dividing the countries by groups, to analysed different kinds of cycles with different types of periods under study.

\section{Recommendations}

- it is required to make positive development and high yield observable not only in the capital of country and some main cities, but also in many regions of the country. Negative trend of the demographic indicators in the Baltic countries may indicate the need to improve the overall national socio-economic status. The improvement of the socio-economic situation can positively influence the real estate market, as the socio-economic factors and the real estate market has a high correlation level, especially over the period, when market participants have the abilities and interest to invest the funds;

- it is important to plan sustainable development in advance. The state is required to enhance cooperation with stakeholders of all kind, in order to provide the opportunity to create more valuable, more resilient building stock that benefits all. For example the use of public facilities in the construction is positively affecting the business sector, not only due to the increase of the working positions and other economic aspects, but also the final construction product is important to the public;

- the regulation of the state economics and real estate market is very important to make the development comply with the sustainable development principles, and over time its significance may have a tendency to rise. Government needs to take a control of the market, not to allow overheats of the market, and to promote sustainable development in the longer term. It is recommended for all market participants analyze in detail and follow the changes in the socio-economic sphere and real estate demand in order to achieve the sustainable market development. 


\section{References}

1. Turcu, C. 2012. Local experiences of urban sustainability: Researching Housing Market Renewal interventions in three English neighbourhoods, Progress in Planning 78: 101-150. http://dx.doi.org/10.1016/j.progress.2012.04.002

2. Menger, C. 1871. Principles of Economics. Translated by J. Dingwall and B. F. Hoselitz, with an introduction by Friedrich A. Hayek. New York: New York University Press. USA: Ludwig von Mises Institute. Available from Internet: http://mises.org/document/595

3. Eurostat. Eurostat regional yearbook $2013 \mathrm{http} / / /$ epp.eurostat.ec.europa.eu/portal/page/portal/product_details/publication?p_product_code=KS-HA13-001

4. Eurostat. European social statistics 2013 edition http://epp.eurostat.ec.europa.eu/portal/page/portal/product_details/publication?p_product_code=KSFP-13-001

5. Smith, A., 1776. An Inquiry into the Nature and Causes of the Wealth of Nations. Available from Internet: http://geolib.com/smith.adam/woncont.html

6. Mill, J. S. 1848. Principles of Political Economy with some of their Applications to Social Philosophy. Available from Internet: http://www.econlib.org/library/Mill/mlP.html

7. Staley, C. E. 1989. A history of economic thought: from Aristotle to Arrow. Great Britain: Marson Lindsay Ross International Ltd, 273 p.

8. Latvijas Vēstnesis oficiālais portāls [Official website of Latvijas Vēstnesis]. NAP2020 stratēgiskie rādītāji [NAP2020 strategic indicators]. Available from Internet: http://likumi.lv/doc.php?id=253919

9. Brīvers, I. 2009. Ko varam mācìties no ekonomikas vēstures? [What can we learn from economic history?] Latvijas tautsaimniecības pagātne, tagadne un perspektīvas [Latvian economy in the past, present and its prospects]. Riga: RTU Publishing House, 58.p.

10. Vanags, J.; Geipele, I.; Grizāns, J.; Auziņš, A.; Geipele, S.; Stāmure, I. 2012. Pilsētu un reǵgionu attīstības mijiedarbības sociāli ekonomiskie aspekti. Zinātniski lietišksā monogrāfija. [Socio-economic aspects of urban and regional development interaction. Applied scientific monograph]. Riga: RTU Publishing house, $120 \mathrm{p}$.

11. Afonso, A.; Sousa, R. M. 2012. The macroeconomic effects of fiscal policy, Applied Economics 44(34): 4439-4454 http://dx.doi.org/10.1080/00036846.2011.591732

12. Liu, J.; London, K. 2013. Modelling housing supply and monetary policy within the context of global economic turbulence, International Journal of Strategic Property Management 17(1): 1-20. http://dx.doi.org/10.3846/1648715X.2012.735273

13. SEB bankas portāls [SEB bank official webpage]. SEB mājokḷu pieejamības indekss. [SEB housing availability index]. Available from Internet http://www.seb.lv/lv/about/press-centre/pieejamibas-indekss

14. Mulliner, E.; Smallbone, K.; Maliene, V. 2013. An assessment of sustainable housing affordability using a multiplecriteria decision making method, Omega 41: 270-279. http://dx.doi.org/10.1016/j.omega.2012.05.002

15. Baek, C.-H.; Park, S.-H. 2012. Changes in renovation policies in the era of sustainability, Energy and Buildings 47: $485-496$. http://dx.doi.org/10.1016/j.enbuild.2011.12.028

16. Huanga, F.; Wangb, F. 2005. A system for early-warning and forecasting of real estate development, Automation in Construction 14: 333-342. http://dx.doi.org/10.1016/j.autcon.2004.08.015

17. Brauers, W. K. M.; Kildienè, S.; Zavadskas, E. K.; Kaklauskas, A. 2013. The construction sector in twenty European countries during the recession 2008-2009 - country ranking by MULTIMOORA, International Journal of Strategic Property Management 17(1): 58-78. http://dx.doi.org/10.3846/1648715X.2013.775194

18. International Monetary Fund, 2013. World Economic Outlook: Transitions and Tensions (October 2013). Available from Internet http://www.imf.org/external/pubs/ft/weo/2013/02/pdf/text.pdf

19. Hwang, S.; Park, M.; Lee, H.-S. 2013. Dynamic analysis of the effects of mortgage-lending policies in a real estate market, Mathematical and Computer Modelling 57: 2106-2120. http://dx.doi.org/10.1016/j.mcm.2011.06.023

20. Finanšu un kapitāla tirgus komisija [Financial and Capital Market Commission]. Pārskats par finanšu un kapitāla tirgu - 2013. gada trešais ceturksnis [An overview of the financial and capital market - the third quarter of 2013]. Available from Internet http://fktk.lv/lv/statistika/parskats_par_finansu_un_kapitala_tirgu/2014-01-06_parskats_par_finansu_un_kapitala_tirgu_2013_gada_otrais_ceturksnis/

21. Jowsey, E. 2011. Real Estate Economics. New York: Palgrave Macmillan, 498 p.

22. Vanags, J. 2007. Investīcijas nekustamajā īpašumā [Investments in real estate]. Riga: RTU Publishing house, $178 \mathrm{p}$.

23. Dreher, A. 2006. Does globalization affect growth? Evidence from a new index of globalization, Applied Economics 38(10): 1091-1110. http://dx.doi.org/10.1080/00036840500392078

24. Eurostat. European statistics database. Available from Internet http://epp.eurostat.ec.europa.eu/portal/page/portal/statistics/search_database

25. Hui, E. C. M.; Chan, K. K. K. 2012. Are the global real estate markets contagious?, International Journal of Strategic Property Management 16(3): 219-235. DOI: 10.3846/1648715X.2011.645904

26. Microsoft Office webpage. Use the Analysis ToolPack to perform complex data analysis. Available from Internet: http://office.microsoft.com/enus/excel-help/correl-HP005209023.aspx

27. European statistical office. Autumn forecast 2013 - EU economy: Gradual recovery, externial risks. Statictical annex. Available from Internet $\mathrm{http} / / / \mathrm{ec}$.europa.eu/economy finance/eu/forecasts/2013 autumn forecast en.htm.

28. Colliers International. Baltic States Real Estate Report 2013 3Q. Available from Internet: http://www.colliers.com/enlv/latvia/insights\#.UtfakfuXDYw

29. Cirtautas, M. 2013. Urban Sprawl of Major Cities in the Baltic States. Architecture and Urban Planning, in RTU scientific proceedings (10) 2013/7. Riga: RTU Publishing house, 72-79.

30. Knaap, G. J. 2008. The sprawl of economics: a response to Jan Brueckner pg.67-88, Toward a Vision of Land in 2015: international perspectives / Edited by Gary C. Cornia and Jim Riddell. Cambridge Lincoln Institute of Land policy, 2008

31. Valsts vienotās datorizētas Zemesgrāmatas portāls [A State Unified Computerised Land Register ]. Statistika [Statistics]. Available from Internet: $\mathrm{http}: / / \mathrm{www} . z e m e s g r a m a t a . l v /$ stat/stat.asp

32. Latvijas centrālās statistikas pārvaldes portāls [Central Statistical Bureau of Latvia]. Statistikas datubāzes.[Statistic database]. Available from Internet: http://www.csb.gov.lv/dati/statistikas-datubazes-28270.html

33. Construction Economics [Экономика строительства]. $3^{\text {rd }}$ edition eds.V.V.Buzyrev. St.Petersbourg: Ltd. „Lider” 2009.-416. ISBN 978-5-49807-1275 .

34. World green building council. The business case for green buildings. Available from Internet http://www.worldgbc.org/activities/business-case

35. Glasson, J.; Marshall, T. 2007. Regional planning. Great Britain: TJ International Ltd, 316 p.

36. Geipele, I.; Kauskale, L. 2013. The Influence of Real Estate Market Cycle on the Development in Latvia, in 11th International Conference on Modern Building Materials, Structures and Techniques, MBMST 2013, Procedia Engineering 57: 327-333. 